Abstracta Iranica Abstracta Iranica

Revue bibliographique pour le domaine irano-aryen

Volume 25 | 2004

Comptes rendus des publications de 2002

s.v. «Suse ». Supplément au Dictionnaire de la Bible, Fasc. 73, 2002, Sumer-Suse, col. 359-512 et fasc. 74 (à paraître).

Rémy Boucharlat

(2) OpenEdition

Journals

Édition électronique

URL : https://journals.openedition.org/abstractairanica/4234

DOI : 10.4000/abstractairanica.4234

ISSN : 1961-960X

Éditeur :

CNRS (UMR 7528 Mondes iraniens et indiens), Éditions de l'IFRI

Édition imprimée

Date de publication : 15 mai 2004

ISSN : 0240-8910

Référence électronique

Rémy Boucharlat, « S.v. « Suse ». Supplément au Dictionnaire de la Bible, Fasc. 73, 2002, Sumer-Suse, col. 359-512 et fasc. 74 (à paraître). », Abstracta Iranica [En ligne], Volume $25 \mid$ 2004, document 59, mis en ligne le 15 mars 2006, consulté le 21 septembre 2021. URL : http://journals.openedition.org/ abstractairanica/4234 ; DOI : https://doi.org/10.4000/abstractairanica.4234

Ce document a été généré automatiquement le 21 septembre 2021.

Tous droits réservés 


\title{
S.v. «Suse ». Supplément au Dictionnaire de la Bible, Fasc. 73, 2002, Sumer-Suse, col. 359-512 et fasc. 74 (à paraître).
}

\author{
Rémy Boucharlat
}

1 Une contribution de toute première importance à l'histoire et l'archéologie iraniennes que l'un des auteurs, le Père Steve († 2001) n'aura pu voir imprimée. Le nombre de pages en typographie serrée suffit à montrer que cet article est en fait une véritable monographie, un document qui, le premier de cette ampleur, embrasse toute l'histoire de Suse depuis ses origines vers 4000 jusqu'à l'époque médiévale. Les trois premiers auteurs connaissent parfaitement le site et sa bibliographie, à laquelle chacun a largement contribué, mais aussi l'ensemble de la documentation archéologique et épigraphique y compris celle qui est encore en partie inédite. Les périodes sassanide et islamique, et la bibliographie seront traitées dans le fascicule suivant.

2 Parmi la masse d'informations qu'apportent ces pages, soulignons l'intérêt du chapitre sur la topographie du site aux différentes époques, les tableaux de stratigraphie comparée et l'historique des travaux, tous extrêmement documentés et précis. L'exposé de l'histoire elle-même du site tient compte des études les plus récentes et actualise l'article déjà paru de certains des auteurs sur l'époque élamite (Iranica Antiqua 15, 1980); il comporte des interprétations parfois assez personnelles des auteurs, comme celle de F. Vallat sur Cyrus usurpateur qui, au demeurant, est ici hors suj et. 
INDEX

Thèmes : 3.1. Est de l'Iran

\section{AUTEURS}

RÉMY BOUCHARLAT

CNRS - Lyon 